\title{
Solution Studies of Copper(II) Complexes as a Contribution to the Study of the Active Site of Galactose Oxidase
}

\author{
Stela Maris de M. Romanowski*, Francielen Tormena, Viviane A. dos Santos, \\ Monique de F. Hermann and Antonio S. Mangrich
}

Departamento de Química, Universidade Federal do Paraná, 81531-990 Curitiba - PR, Brazil

\begin{abstract}
Reportamos neste trabalho, a síntese, e a caracterização em solução dos compostos de coordenação de cobre (II) $-\left[\mathrm{Cu}^{\mathrm{II}}\left(\mathrm{H}_{2}\right.\right.$ bbpeten $\left.)\right]\left(\mathrm{NO}_{3}\right)_{2},\left[\mathrm{H}_{2}\right.$ bbpeten $=N$-(2-hidroxibenzil)- $N, N$ '-bis(2-piridilmetil)$N^{\prime}$-(2-hidroxietil)etilenodiamina]; [Cu $\left(\mathrm{H}_{3}\right.$ bpeten) $]\left(\mathrm{NO}_{3}\right)_{2},\left[\mathrm{H}_{3}\right.$ bpten $=N, N^{\prime}$-bis-(2-hidroxibenzil)$N$-(2-piridilmetil)- $N$ '-(2-hidroxietil)etilenodiamina]; [Cu' $($ Hnbbpeten) $] \mathrm{NO}_{3}$, [ $\mathrm{H}_{2}$ nbbpeten, $N$-(5-nitro2-hidroxibenzil)- $N, N^{\prime}$-bis(2-piridilmetil)- $N$ '-(2-hidroxietil)etilenodiamina] e [Cu$\left.{ }^{\mathrm{II}}(\mathrm{Hbnbpeten})\right]$, $\left[\mathrm{H}_{3}\right.$ bnbpeten $=N, N^{\prime}$-bis-(5-nitro-2-hidroxibenzil)- $N$-(2-piridilmetil)- $N$ ' - (2-hidroxietil)etilenodiamina $]$ - com ligantes polidentados assimétricos N,O-doadores. Dois destes ligantes apresentam grupos $\mathrm{NO}_{2}$ em posição para aos grupos fenólicos. Estudos eletroquímicos foram realizados para os ligantes livres e para os complexos de cobre(II).
\end{abstract}

The synthesis and solution characterization of the coordination compounds $\left[\mathrm{Cu}^{\mathrm{II}}\left(\mathrm{H}_{2}\right.\right.$ bbpeten $\left.)\right]\left(\mathrm{NO}_{3}\right)_{2},\left[\mathrm{H}_{2}\right.$ bbpeten $=N$-(2-hydroxybenzyl)- $N, N^{\prime}$-bis (2-pyridylmethyl)- $N^{\prime}-(2-$ hydroxyethyl)ethane-1,2-diamine $] ;\left[\mathrm{Cu}^{\mathrm{II}}\left(\mathrm{H}_{3}\right.\right.$ bpeten $\left.)\right]\left(\mathrm{NO}_{3}\right)_{2},\left[\mathrm{H}_{3}\right.$ bpten $=N, N$ ' - bis- (2-hydroxybenzyl) - $N$-(2-pyridylmethyl)- $N$ '-(2-hydroxyethyl)ethane-1,2-diamine]; [Cu $\mathrm{Cu}^{\mathrm{II}}(\mathrm{H}$ bbpeten) $] \mathrm{NO}_{3},\left[\mathrm{H}_{2}\right.$ nbbpeten $=N$-(5-nitro-2-hydroxybenzyl)- $N, N^{\prime}$-bis(2- pyridylmethyl)- $N^{\prime}$-(2-hydroxyethyl)ethane-1,2-diamine $]$ and $\left[\mathrm{Cu}^{\mathrm{II}}(\mathrm{Hbnbpeten})\right],\left[\mathrm{H}_{3}\right.$ bnbpeten $=N, N^{\prime}$-bis-(5-nitro-2-hydroxybenzyl)- $N$-2-pyridylmethyl)$N^{\prime}$-(2-hydroxyethyl)ethane-1,2-diamine] - are reported as copper(II) complexes containing alcoholic, pyridine and phenolic arms. Two of the ligands bear a $\mathrm{NO}_{2}$ group at the para position of one or two of the phenolic moieties. Electrochemical studies have been performed for the proligands and for the copper complexes.

Keywords: $\mathrm{Cu}^{\mathrm{II}}$ complexes, electrochemical properties, EPR, galactose oxidase

\section{Introduction}

Organic synthesis of unsymmetrical multidentate ligands that are necessary to enforce the desired coordination environments of the metal ions, has played an important role in the design of the active site of metalloprotein analogues. ${ }^{1,2}$

Copper in its various roles in biological systems displays different spectroscopic and chemical properties presumably because of the different ligand environments and coordination numbers. ${ }^{3}$

Galactose oxidase (Goase) is a mononuclear copper metalloenzyme which catalyses the oxidation of several primary alcohols to aldehydes. The geometry around the monomeric copper(II) center in galactose oxidase extracted from the fungus Fusarium dendroides at $\mathrm{pH} 4.5$ can be

* e-mail: stela@quimica.ufpr.br described as square pyramidal, comprised of one tyrosyl oxygen atom, two histidine nitrogen atoms and one acetate oxygen atom in the plane and of a tyrosine oxygen atom occupying the apical position of the pyramid. ${ }^{4,5}$

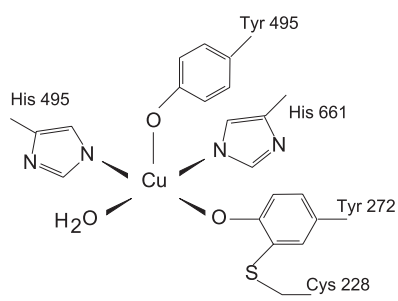

Figure 1. Design of the galactose oxidase active site, crystallografically characterized.

In the active and oxidized Goase form the enzyme contains coordinated Tyr-272. Unusual features of Tyr272 are a thioether link in the ortho-position of the phenolate oxygen formed by the covalent binding to the 
S-atom of Cys-228. The major role of this thioether group is the lowering of the oxidation potential of the tyrosine, stabilizing the phenoxide oxidation product by several hundred millivolts. ${ }^{6-9}$

Thus the study of variously substituted proligands belonging to the same series seemed an essential prerequisite to the understanding and, consequently, the control of redox properties of the corresponding copper complexes.

We describe here solution studies of four copper(II) complexes derived from four unsymmetrical N,O-donor polyfunctional ligands, two of which bear no substituent at the phenol moieties (L1 and L2) $)^{10-12}$ and two which bear the electron-withdrawing $-\mathrm{NO}_{2}$ group at one or two of the phenol moieties (L3 and L4). These four compounds have been designed with the aim of studying the effect of $-\mathrm{NO}_{2}$ group on the physicochemical properties of the copper complexes.

\section{Experimental}

\section{Abbreviations}

The following abbreviations are used throughout the text: $\mathrm{H}_{2}$ bbpeten, $N$-(2-hydroxybenzyl)- $N, N$ '-bis(2-pyridylmethyl)- $N^{\prime}$-(2-hydroxyethyl) ethane-1,2-diamine; $\mathrm{H}_{3}$ bpten, $N, N$ '-bis-(2-hydroxybenzyl)- $N$-(2-pyridylmethyl)- $N$ ' -(2hydroxyethyl)ethane-1,2-diamine; $\mathrm{H}_{2}$ nbbpeten, $\mathrm{N}$-(5-nitro2-hydroxybenzyl)- $N, N^{\prime}$-bis(2-pyridylmethyl)- $N^{\prime}$-(2hydroxyethyl)ethane-1,2-diamine; $\mathrm{H}_{3}$ bnbpeten, $N, N^{\prime}$-bis(5-nitro-2-hydroxybenzyl)- $N$-(2-pyridylmethyl)- $N$ '-(2hydroxyethyl)ethane-1,2-diamine; $\mathrm{H}_{2}$ beten, $N$-(2-hydroxybenzyl)- $N$ '-(2-hydroxyethyl)ethane-1,2-diamine; Hpeten, $N$-(2-pyridylmethyl)- $N^{\prime}$-(2-hydroxyethyl)ethane-1,2diamine; $\mathrm{H}_{2}$ nbeten, $N$-(5-nitro-2-hydroxybenzyl)- $N$ '-(2hydroxyethyl)ethane-1,2-diamine; $\mathrm{H}_{3}$ bnbeten, $N, N^{\prime}$-bis-(5nitro-2-hydroxybenzyl)-N'-(2-hydroxyethyl)ethane-1,2diamine; $\mathrm{Et}_{3} \mathrm{~N}$, triethylamine; $\mathrm{TBAPF}_{6}$, tetrabutylammonium hexafluorophosphate; $\mathrm{Fc}^{+} / \mathrm{Fc}$, ferrocinium/ferrocene.

\section{Materials}

2-hydroxybenzyl alcohol (salicyl alcohol), 2-hydroxybenzaldehyde (salicylaldehyde), 2-pyridylcarboxyaldehyde, 2-bromomethylphenol, 2-hydroxy-5nitrobenzaldehyde (5-nitrosalicylaldehyde), 2-picolyl chloride hydrochloride, $N$-(2-hydroxyethyl)ethylenediamine, 2-hydroxy-5-nitrobenzyl bromide ( $\alpha$-bromo-4nitro- $O$-cresol), copper nitrate trihydrated and tetrabutylammonium hexafluorophosphate were obtained from Aldrich Chemical Co. For electrochemical and spectros- copic studies, high-purity solvents were used as received from Merck. High-purity nitrogen was used to deoxygenate solutions. All other chemicals and solvents were reagent grade.

\section{Synthesis}

$\mathrm{H}_{2}$ bbpeten, $(\boldsymbol{L 1}) .^{10,12}$ This unsymmetric compound was obtained according to Scheme 1. The first step was a condensation reaction of $\mathrm{N}$-(2-hydroxyethyl)ethylenediamine $(2.60 \mathrm{~g}, 25 \mathrm{mmol})$ and salicylaldehyde $(3.05 \mathrm{~g}$, $25 \mathrm{mmol})$ followed by reduction with $\mathrm{NaBH}_{4}(1.90 \mathrm{~g}, 50$ $\mathrm{mmol}$ ) in methanol producing $\mathrm{N}$-(2-hydroxybenzyl)-N'(2-hydroxyethyl)ethane-1,2-diamine ( $\mathrm{H}_{2}$ beten). The final unsymmetric hexadentate proligand was synthesized by nucleophilic substitution of 2-(chloromethyl)pyridine hydrochloride $(8.20 \mathrm{~g}, 50 \mathrm{mmol})$ previously neutralized with $\mathrm{NaOH} 4 \mathrm{~mol} \mathrm{~L}{ }^{-1}$ with $\mathrm{H}_{2}$ beten $(5.25 \mathrm{~g}, 25 \mathrm{mmol})$. Sodium hydroxide ( $4 \mathrm{~mol} \mathrm{~L}^{-1}, 5 \mathrm{~mL}$ ) was added very slowly to the stirred and in a cool bath reaction.

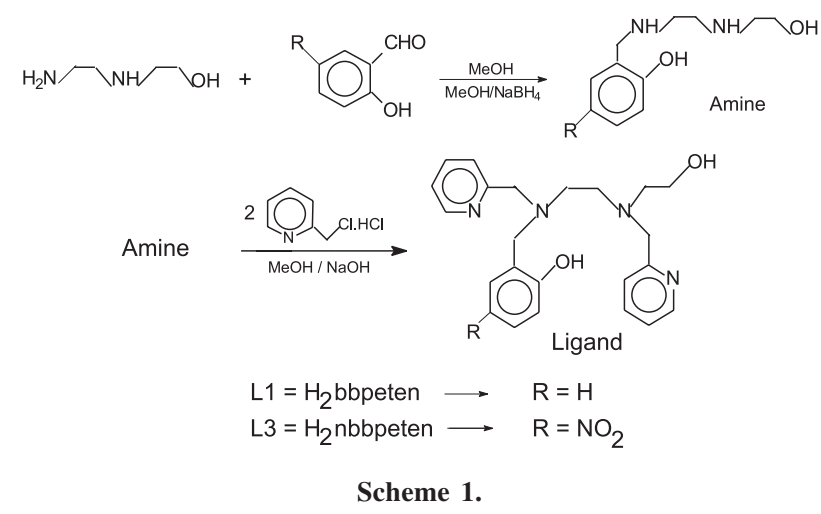

The proligand was extracted with eight $50 \mathrm{~mL}$ portions of $\mathrm{CHCl}_{3}$, and the extracts were combined, washed with brine, dried over anhydrous $\mathrm{MgSO}_{4}$, filtered and concentrated under reduced pressure. The crude product was purified by silica gel column chromatography employing ethanol-water (3:1) as eluent to afford $8.60 \mathrm{~g}$ (87.8\%) of a yellow oil. IR $v_{\max } / \mathrm{cm}^{-1}: v(\mathrm{O}-\mathrm{H}), 3250 ; v(\mathrm{C}=\mathrm{N}$, $\mathrm{C}=\mathrm{C}), 1592,1484,1436 ; \delta(\mathrm{O}-\mathrm{H}), 1368 ; v(\mathrm{C}-\mathrm{O}), 1252$. Anal. Calc. for $\mathrm{C}_{23} \mathrm{H}_{28} \mathrm{~N}_{4} \mathrm{O}_{2} \cdot \mathrm{H}_{2} \mathrm{O}: \mathrm{C}, 67.31 ; \mathrm{H}, 7.32 ; \mathrm{N}, 13.66$. Found: C, 68.5; H, 7.5; N, 13.4\%.

$H_{3}$ bpeten, (L2). ${ }^{11,12}$ This compound was obtained according to Scheme 2. The first step was a condensation reaction of $\mathrm{N}$-(2-hydroxyethyl) ethylenediamine ( $2.60 \mathrm{~g}$; $25 \mathrm{mmol}$ ) with 2-pyridinecarboxyaldehyde (2.68 g; 25 $\mathrm{mmol})$, followed by reduction with $\mathrm{NaBH}_{4}(1.90 \mathrm{~g} ; 50 \mathrm{mmol})$ in methanol, producing $\mathrm{N}$-(2-pyridylmethyl)-N'-(2hydroxyethyl)ethane-1,2-diamine (Hpeten). The final unsymmetric hexadentate proligand was synthesized by 
nucleophilic substitution of the 2-bromomethylphenol (3.74 g; $20 \mathrm{mmol}$ ), with Hpeten (1.95 g; $10 \mathrm{mmol}$ ) in $50 \mathrm{~mL}$ of tetrahydrofuran under argon atmosphere. After the addition of $\mathrm{Et}_{3} \mathrm{~N}(22 \mathrm{mmol})$ and stirring for $24 \mathrm{~h}$, a precipitate of $\mathrm{Et}_{3} \mathrm{NHBr}$ formed, which was removed by filtration. After rotatory evaporation, a yellow oil was obtained. The proligand was extracted with eight $50 \mathrm{~mL}$ portions of $\mathrm{CHCl}_{3}$, and the extracts were combined, washed with brine, dried over anhydrous $\mathrm{MgSO}_{4}$ and concentrated under reduced pressure. After concentration, the desired proligand was precipitated with acetone, filtered off, washed with propan2-ol and dried under vacuum. The $\mathrm{H}_{3}$ bpeten was obtained as a pale yellow solid. Yield: $3.20 \mathrm{~g}(78.5 \%), \mathrm{mp}=157^{\circ} \mathrm{C}$. Anal. Calc. for $\mathrm{C}_{24} \mathrm{H}_{29} \mathrm{~N}_{3} \mathrm{O}_{3} .2 \mathrm{C}_{3} \mathrm{H}_{8} \mathrm{O}: \mathrm{C}, 68.24 ; \mathrm{H}, 7.01 ; \mathrm{N}$, 7.97. Found: $\mathrm{C}, 68.2 ; \mathrm{H}, 7.1 ; \mathrm{N}, 7.5 \%$. IR $v_{\max } / \mathrm{cm}^{-1}: v(\mathrm{O}-\mathrm{H})$, 3188; $v(\mathrm{C}=\mathrm{N}, \mathrm{C}=\mathrm{C}), 1592,1488,1456$ and 1438; $\delta(\mathrm{O}-\mathrm{H})$, 1368; $v(\mathrm{C}-\mathrm{O}), 1252$.

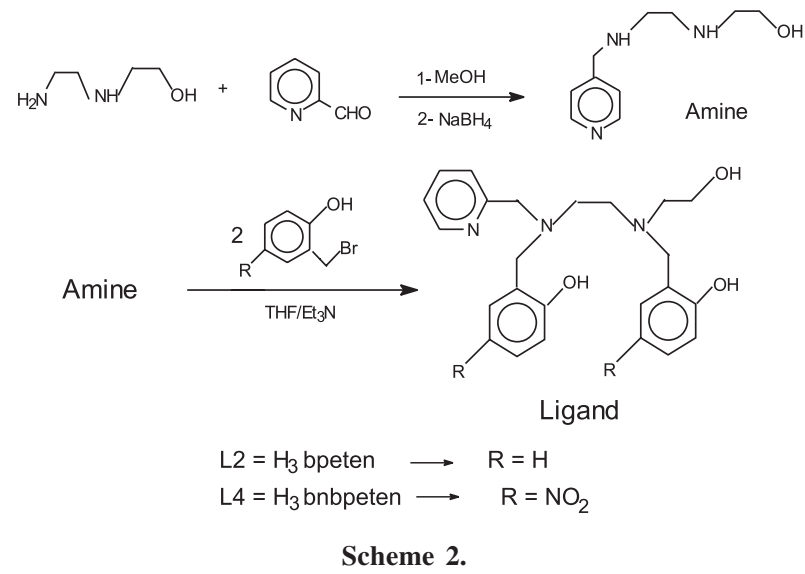

$\mathrm{H}_{2}$ nbbpeten, ( $\left.\mathbf{L 3}\right)$. This was also obtained according to Scheme 1, using 5-nitro-salicylaldehyde instead of salicylaldehyde. The $\mathrm{H}_{2}$ nbbpeten was obtained as a pale yellow oil. Yield: $4.08 \mathrm{~g}$ (99.6\%). Anal. Calc. for $\mathrm{C}_{23} \mathrm{H}_{27} \mathrm{~N}_{5} \mathrm{O}_{4}: \mathrm{C}, 63.14 ; \mathrm{H}, 6.22 ; \mathrm{N}, 16.01$. Found: $\mathrm{C}, 63.2$; $\mathrm{H}, 6.1 ; \mathrm{N}, 15.9 \%$. IR $v_{\text {max }} / \mathrm{cm}^{-1}: v(\mathrm{O}-\mathrm{H}), 3292 ; v(\mathrm{C}=\mathrm{N}, \mathrm{C}=\mathrm{C})$, $1617,1589,1512$ and 1434; $\delta(\mathrm{O}-\mathrm{H}), 1335 ; \nu(\mathrm{C}-\mathrm{O}), 1287$; $\delta_{\text {assim }}(\mathrm{N}=\mathrm{O})_{2}, 1589 ; \delta_{\text {sim }}(\mathrm{N}=\mathrm{O})_{2}, 1287$ and $\delta_{\mathrm{C}-\mathrm{N}}\left(\mathrm{ArNO}_{2}\right), 834$.

$\mathrm{H}_{3}$ bnbpeten, $(\boldsymbol{L A})$. This was also obtained according to Scheme 2, using 2-hydroxy-5-nitrobenzyl bromide instead the 2-bromomethylphenol. The $\mathrm{H}_{3}$ bnbpeten was obtained as a yellow solid. Yield: $3.18 \mathrm{~g}(91.4 \%), \mathrm{mp}=208^{\circ} \mathrm{C}$. Anal. Calc. for $\mathrm{C}_{24} \mathrm{H}_{27} \mathrm{~N}_{5} \mathrm{O}_{7}:$ C, 57.95; H, 5.43; N, $14.08 \%$. Found: C, 58.2; H, 5.3; N, 14.6\%. IR $v_{\max } / \mathrm{cm}^{-1}: v(\mathrm{O}-\mathrm{H})$, $3478 ; v(\mathrm{C}=\mathrm{N}, \mathrm{C}=\mathrm{C}), 1.663,1.597,1.538$ and $1.418 ; \delta(\mathrm{O}-$ $\mathrm{H}), 1343 ; v(\mathrm{C}-\mathrm{O}), 1280 ; \delta_{\text {assim }}(\mathrm{N}=\mathrm{O})_{2}, 1597 ; \delta_{\text {sim }}(\mathrm{N}=\mathrm{O})_{2}$, 1280 and $\delta_{\mathrm{C}-\mathrm{N}}\left(\mathrm{ArNO}_{2}\right), 829$.

$\left[\mathrm{Cu} \mathrm{u}^{I I}\left(\mathrm{H}_{2}\right.\right.$ bbpeten $\left.)\right]\left(\mathrm{NO}_{3}\right)_{2},(\mathrm{I}),\left[\mathrm{Cu}^{I I}\left(\mathrm{H}_{3}\right.\right.$ bpeten $\left.)\right]\left(\mathrm{NO}_{3}\right)_{2}$, (2), [Cu ${ }^{I I}($ Hnbbpeten) $] \mathrm{NO}_{3}$, (3) and [Cu II Hbnbpeten)], (4). The coordination compounds were prepared by refluxing a methanolic solution of $\mathrm{Cu}\left(\mathrm{NO}_{3}\right)_{2} \cdot 3 \mathrm{H}_{2} \mathrm{O}(0.24 \mathrm{~g}, 1.0 \mathrm{mmol})$ and the four proligands: $\mathrm{H}_{2}$ bbpeten $-\mathrm{L} 1(0.41 \mathrm{~g}, 1.0 \mathrm{mmol})$, $\mathrm{H}_{3}$ bpeten - L2 (0.53 g, $\left.1.0 \mathrm{mmol}\right), \mathrm{H}_{2}$ nbbpeten - L3 (0.44 g, $1.0 \mathrm{mmol})$ and $\mathrm{H}_{3}$ bnbpeten - L4 (0.50 g, $\left.1.0 \mathrm{mmol}\right)$, with magnetic stirring for $1 \mathrm{~h}$. All four reactions yield dark green precipitates, which were recrystallized in an acetonitrilepropan-2-ol (1:1) solution at room temperature. After a few days microcrystalline solids were filtered off, washed with propan-2-ol and dried with ether. The green crystals were unfortunately not suitable for X-ray diffraction measurements. Yield: (1) $0.32 \mathrm{~g}(55,2 \%)$, (2) $0.34 \mathrm{~g}(57.6 \%)$, (3) $0.38 \mathrm{~g}(56.6 \%)$ and (4) $0.30 \mathrm{~g}(53.6 \%)$. Anal. Calc. for $\mathrm{CuC}_{23} \mathrm{H}_{28} \mathrm{~N}_{4} \mathrm{O}_{2}\left(\mathrm{NO}_{3}\right)_{2}$ (1): C, 47.63; H, 4.83; N, $14.50 \%$. Found: C, 47.8; $\mathrm{H}, 4.6 ; \mathrm{N}, 14.3 \%$. $\mathrm{CuC}_{24} \mathrm{H}_{29} \mathrm{~N}_{3} \mathrm{O}_{3}\left(\mathrm{NO}_{3}\right)_{2}(2)$ : C, 48.44; H, 4.63; N, 11,77\%. Found: C, 48.8; H, 4.8; N, $11.7 \% . \mathrm{CuC}_{23} \mathrm{H}_{26} \mathrm{~N}_{5} \mathrm{O}_{4} \cdot \mathrm{NO}_{3}(3): \mathrm{C}, 49.15 ; \mathrm{H}, 4.32 ; \mathrm{N}, 14.96 \%$. Found: $\mathrm{C}, 49.2 ; \mathrm{H}, 4.8 ; \mathrm{N}, 15.1 \% . \mathrm{CuC}_{24} \mathrm{H}_{25} \mathrm{~N}_{5} \mathrm{O}_{7}$ (4): C, 51.47; H, 4.64; N, 12.51\%. Found: C, 50.9; H, 4.6; N, $12.6 \%$.

\section{Physical measurements}

IR spectra were obtained on a FT-IR BOMEN MICHELSON model MB spectrometer in KBr-disk or Nujol film. Elemental analyses were performed on a Perkin Elmer model 2400. EPR spectra were measured at $298 \mathrm{~K}$ and $77 \mathrm{~K}$ in a Bruker ESP 300E spectrometer. Molar Conductivity was measured in $\operatorname{DMF}\left(10^{-3} \mathrm{~mol} \mathrm{~L}^{-1}\right)$ at $298 \pm$ $0.1 \mathrm{~K}$ with a Digimed CD-21. Visible and NIR spectra were recorded in DMF with a SHIMADZU model 2401 spectrometer. Cyclic voltammetry experiments were performed with a PAR 273 (Princeton Applied Research) in $\mathrm{CH}_{3} \mathrm{CN}$ under argon at room temperature with $0.1 \mathrm{~mol} \mathrm{~L}^{-1}$ $[\mathrm{TBA}]\left[\mathrm{PF}_{6}\right]$ as the supporting electrolyte. Cyclic voltammograms were obtained by using a standard threecomponent system consisting of a carbon disk working electrode, a platinum wire auxiliary electrode, and an $\mathrm{Ag} / \mathrm{AgCl}$ reference electrode. The $\mathrm{Fc}^{+} / \mathrm{Fc}$ couple ${ }^{13}$ was used to monitor the reference electrode and was observed at $+0.406 \mathrm{~V}$ vs. Ag/AgCl.

\section{Results and Discussion}

\section{Syntheses}

The $\mathrm{H}_{2}$ bbpeten, $\mathrm{H}_{3}$ bpeten, $\mathrm{H}_{2}$ nbbpeten and $\mathrm{H}_{3}$ bnbpeten characterization were established unambiguously by elemental analysis, and IR spectroscopy. They react in methanolic solution with $\mathrm{Cu}\left(\mathrm{NO}_{3}\right)_{2} \cdot 3 \mathrm{H}_{2} \mathrm{O}$ to form the stable $\left[\mathrm{Cu}^{\mathrm{II}}\left(\mathrm{H}_{2}\right.\right.$ bbpeten $\left.)\right]\left(\mathrm{NO}_{3}\right)_{2},(\mathbf{1}),\left[\mathrm{Cu}^{\mathrm{II}}\left(\mathrm{H}_{2}\right.\right.$ bpeten $\left.)\right]\left(\mathrm{NO}_{3}\right)_{2},(\mathbf{2})$, $\left[\mathrm{Cu}^{\mathrm{II}}(\right.$ Hnbbpeten $\left.)\right] \mathrm{NO}_{3},(\mathbf{3})$ and $\left[\mathrm{Cu}^{\mathrm{II}}(\right.$ Hbnbpeten $\left.)\right]$, (4), which were isolated in good yields. 
The IR spectra of 1, 2,3 and $\mathbf{4}$ are similar to those of the proligands. They differ only in: (a) appearance of one well defined band at 3420,3388, 3055 and $3416 \mathrm{~cm}^{-1}$, respectively, attributed to the $v(\mathrm{O}-\mathrm{H})$ stretching of uncoordinated primary alcohol; (b) the $\delta(\mathrm{O}-\mathrm{H})$ in-plane bending of the phenol of the compounds $\mathbf{3}$ and $\mathbf{4}$, at 1343 $\mathrm{cm}^{-1}$, compared to those observed in the proligands, indicating that the phenol groups are deprotonated and coordinated; (c) row of bands at 1384 and $1268 \mathrm{~cm}^{-1}$ in the spectrum of $\mathbf{1}, \mathbf{2}$, and $\mathbf{3}$, attributed to $v(\mathrm{~N}-\mathrm{O})$ of the $\mathrm{NO}_{3}$ counterion.

The molar conductivities of $\mathbf{1 , 2}$ and $\mathbf{3}$, in DMF at $298 \mathrm{~K}$ are 154,158 and $87 \Omega^{-1} \mathrm{~cm}^{2} \mathrm{~mol}^{-1}$, respectively, which are consistent with 2:1, 2:1 and 1:1 electrolytes. The molar conductivity of $\mathbf{4}$ in DMF solution at $298 \mathrm{~K}$ is insignificant which is consistent with it being a neutral coordination compound. ${ }^{14}$

\section{Electronic absorption and electron paramagnetic resonance spectra}

The electronic spectra of $\mathbf{1}, \mathbf{2}, \mathbf{3}$ and $\mathbf{4}$, measured in DMF in the visible region are shown in Figure 2 and reveal the following transitions at $\lambda_{\max } / \mathrm{nm}\left(\varepsilon / \mathrm{L} \mathrm{mol}^{-1} \mathrm{~cm}^{-1}\right): 426$ (280) and 650 (111) for 1; 424 (405) and 633 (114) for 2 ; 387 (12,273), 473 (355) and 657 (111) for 3 and 390 $(18,965)$ and 659 (117) for 4 that can be associated with metal-ligand coordination. Copper(II) ions can adopt square-planar, square-pyramidal, trigonal-bipyramidal, octahedral and tetrahedral geometries, which, except for the first, are generally distorted from the idealized structures. The d-d spectra shown by these coordination geometries are distinctive only in the case of the tetrahedral environment where the absorptions occur at much lower energies and generally show, in the distorted forms, wellseparated absorption peaks; all the other geometries show closely spaced absorption manifolds. ${ }^{3}$ The intense absorbance bands occurring at 387 and $390 \mathrm{~nm}$ for $\mathbf{3}$ and 4, respectively, are assigned to $\mathrm{Cu}^{\mathrm{II}} \rightarrow \mathrm{O}^{-}$axial and/or $\mathrm{O}_{\text {equatorial }}^{-} \rightarrow \mathrm{Cu}^{\mathrm{II}}$ charge-transfer transitions. The bands in the ranges 659-633 (broad and distorted) and 424-473 nm are due to $\mathrm{d}-\mathrm{d}$ transitions and suggest that the $\mathrm{Cu}^{\mathrm{II}}$ atoms in the these complexes have similar distorted squarepyramidal geometries. ${ }^{3,15-17}$

The visible absorption spectrum of galactose oxidase is characterized by three absorption bands having molar extinction coefficients of the order of $1000 \mathrm{~L} \mathrm{~mol}^{-1} \mathrm{~cm}^{-1}$ These occur at 444, 630 and $775 \mathrm{~nm}$, the last two being broad and overlapping. The bands at 630 and $775 \mathrm{~nm}$ are assigned to $d-d$ transitions and suggest that the copper(II) ion in the enzyme is in a somewhat distorted five-

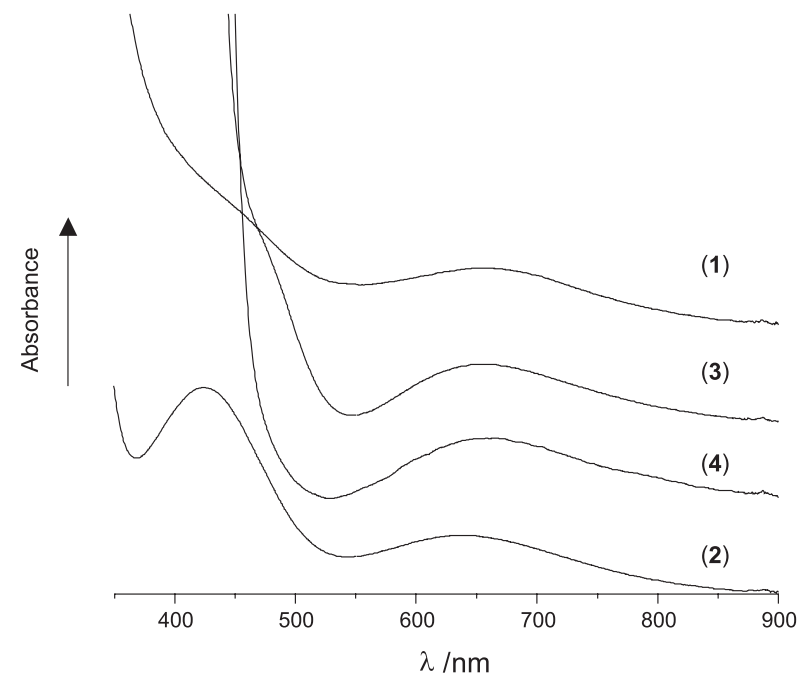

Figure 2. Electronic spectra of 1, 2, 3 and 4 in DMF, $10^{-3} \mathrm{~mol} \mathrm{~L}^{-1}$.

coordinated environment. ${ }^{3,16}$ Thus, of the four copper (II) compounds described in this work, the $\left[\mathrm{Cu}\left(\mathrm{H}_{3}\right.\right.$ bpeten $\left.)\right]\left(\mathrm{NO}_{3}\right)_{2},(2)$ has chromophoric properties most similar to those found in the enzyme.

Table 1. Electronic spectra data for the copper(II) compounds in DMF, and for GOase ${ }^{16}$

\begin{tabular}{ll}
\hline Compound & $\lambda_{\max } / \mathrm{nm}\left(\varepsilon / \mathrm{mol}^{-1} \mathrm{~L} \mathrm{~cm}^{-1}\right)$ \\
\hline$\left[\mathrm{Cu}\left(\mathrm{H}_{2}\right.\right.$ bbpeten $\left.)\right]\left(\mathrm{NO}_{3}\right)_{2},(\mathbf{1})$ & $650(111)$ and $426(280)$ \\
{$\left[\mathrm{Cu}\left(\mathrm{H}_{3}\right.\right.$ bpeten $\left.)\right]\left(\mathrm{NO}_{3}\right)_{2},(\mathbf{2})$} & $633(114)$ and $424(405)$ \\
{$[\mathrm{Cu}($ Hnbbpeten $)] \mathrm{NO}_{3},(\mathbf{3})$} & $657(111) ; 473(355)$ and \\
& $387(12,273)$ \\
{$[\mathrm{Cu}(\mathrm{Hbnbpeten},(\mathbf{4})$} & $665(73)$ and $390(18,965)$ \\
Goase $^{16}$ & $775(905) ; 630(1015)$ \\
& and 444(1155) \\
\hline
\end{tabular}

The X-band EPR spectrum of a frozen solution of 1, 2, 3 and 4, in DMF are shown in Figure 3. The Hamiltonian parameters obtained from the spectra of these compounds and for Goase are resumed in Table 2.

The EPR spectra of the four copper(II) coordination compounds described here, indicate axial symmetry. For all four complexes, $\mathrm{g}_{\mathrm{II}}>\mathrm{g}_{\perp}>2$, suggesting distorted tetragonal, square-pyramidal or square-planar geometry. Moreover, the $\mathrm{g}_{\mathrm{II}}$ and $\mathrm{A}_{\text {II }}$ values of $\mathrm{Cu}\left[\left(\mathrm{H}_{2}\right.\right.$ bbpeten $\left.)\right]\left(\mathrm{NO}_{3}\right)_{2}$, $\left[\mathrm{Cu}\left(\mathrm{H}_{3}\right.\right.$ bpeten $\left.)\right]\left(\mathrm{NO}_{3}\right)_{2}, \quad[\mathrm{Cu}($ Hnbbpeten $)] \mathrm{NO}_{3}$ and $[\mathrm{Cu}($ Hbnbpeten $)]$ are found in the regions characteristic of $\mathrm{CuN}_{4}$ and $\mathrm{CuN}_{3} \mathrm{O}$ chromophores in the $\mathrm{g}_{\text {II }}$ vs. $\mathrm{A}_{\text {II }}$ diagram and near the value of galactose oxidase. Sagakushi and Addison ${ }^{19}$ showed that the $\mathrm{g}_{\mathrm{II}} / \mathrm{A}_{\mathrm{II}}$ ratio can be used as a convenient empirical index of tetrahedral distortion in $\mathrm{CuN}_{4}$ units. This value ranges from $c a .105$ to $135 \mathrm{~cm}$ for square-planar structure, and this quotient increases on the introduction of tetrahedral distortion to the chromophore. 
Table 2. Parameters $g, A\left(\mathrm{x} 10^{-4} \mathrm{~cm}^{-1}\right)$ and $\mathrm{g}_{\mathrm{II}} / \mathrm{A}_{\mathrm{II}}$ ratio for the compounds $\mathbf{1}, \mathbf{2}, \mathbf{3}$ and $\mathbf{4}$ and for GOase ${ }^{18}$

\begin{tabular}{lccccc}
\hline Compound & $\mathrm{g}_{\mathrm{x}}$ & $\mathrm{g}_{\mathrm{y}}$ & $\mathrm{g}_{\mathrm{z}}$ & $\mathrm{A}_{\mathrm{z}}$ & $\mathrm{g}_{\mathrm{II}} / \mathrm{A}_{\text {II }}$ \\
\hline $\mathrm{Goase}^{18}$ & 2.058 & 2.048 & 2.273 & 176.5 & 129 \\
$\mathrm{Cu}\left[\left(\mathrm{H}_{2}\right.\right.$ bbpeten $\left.)\right]\left(\mathrm{NO}_{3}\right)_{2},(\mathbf{1})$ & 2.071 & 2.071 & 2.225 & 182.6 & 122 \\
{$\left[\mathrm{Cu}\left(\mathrm{H}_{2}\right.\right.$ bpeten $\left.)\right]\left(\mathrm{NO}_{3}\right)_{2},(\mathbf{2})$} & 2.055 & 2.055 & 2.215 & 186.7 & 118 \\
{$[\mathrm{Cu}($ Hnbbpeten $)] \mathrm{NO}_{3},(\mathbf{3})$} & 2,035 & 2,035 & 2.231 & 181.6 & 123 \\
{$[\mathrm{Cu}($ Hbnbpeten $)],(\mathbf{4})$} & 2,040 & 2,040 & 2,241 & 178.6 & 125 \\
\hline
\end{tabular}

Further, tetrahedral distortion of a square-planar chromofore is observed when any of biomimetic $(\mathrm{N}, \mathrm{O}, \mathrm{S})$ donors reduces $\mathrm{A}_{/ /}$and increases $\mathrm{g}_{\| /}$. Using that relationship and the results in Table 2, all the four compounds have a slightly tetrahedral distortion, that is, they seemed to be square-pyramidal. Probably the nitrogen atoms of $\mathbf{L 1}$ and $\mathbf{L 3}$ are in the equatorial plane of the respective compounds 1 and 3 . For the compounds $\mathbf{2}$ and $\mathbf{4}$ the equatorial ligand sets of the copper(II) ion are composed of three nitrogen atoms and one oxygen atom.

The increased $\mathrm{g}_{/ /}$values and decreased $\mathrm{A}_{/ /}$values in the compounds 2, 1, 3 and 4, respectively, show that the ligand field strength decreases in these compounds in the same order. The complex $\left[\mathrm{Cu}\left(\mathrm{H}_{3}\right.\right.$ bpeten $\left.)\right]\left(\mathrm{NO}_{3}\right)_{2},(2)$ has a stronger ligand field than $\left[\mathrm{Cu}\left(\mathrm{H}_{2}\right.\right.$ bbpeten $\left.)\right]\left(\mathrm{NO}_{3}\right)_{2}$, $[\mathrm{Cu}($ Hnbbpeten $)] \mathrm{NO}_{3}$ and $[\mathrm{Cu}($ Hbnbpeten $)]\left(\mathrm{A}_{/ /}=186.7 \mathrm{vs}\right.$. $182.6,181.6$ and $178.6 \times 10^{-4} \mathrm{~cm}^{-1}$ and $\mathrm{g}_{\|}=2.215$ vs. 2.225 ,

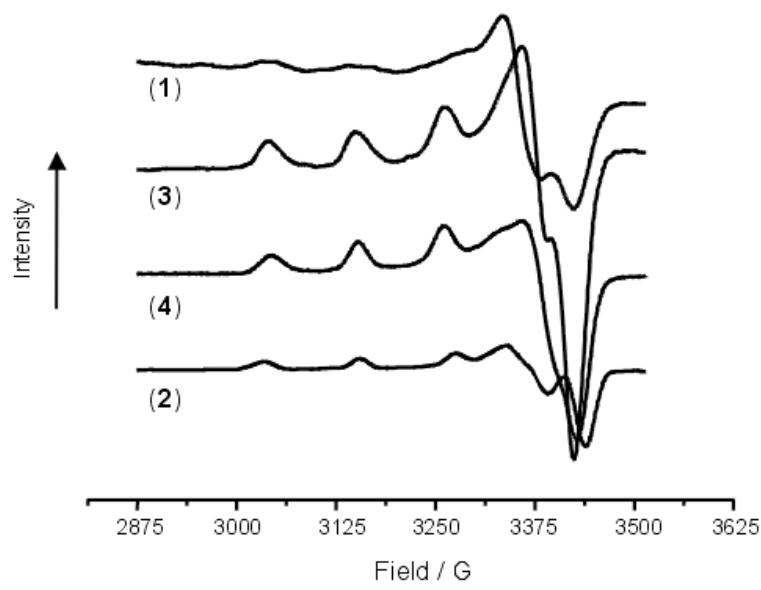

Figure 3. X-band EPR spectra of $\mathbf{1}, \mathbf{2}, \mathbf{3}$ and $\mathbf{4}$ in DMF at $77 \mathrm{~K}$. The Hamiltonian parameters are: $\mathrm{g}_{\perp}=2.071, \mathrm{~g}_{\mid}=2.225$ and $A_{\mu}=182.6$ x $10^{-4} \mathrm{~cm}^{-1}$ for (1); $\mathrm{g}_{\perp}=2.055, \mathrm{~g}_{||}=2.215$ and $A_{\|}=186.7 \times 10^{-4} \mathrm{~cm}^{-1}$ for $2 ; \mathrm{g}_{\perp}=2.035, \mathrm{~g}_{||}=2.231$ and $A_{||}=181.6 \times 10^{-4} \mathrm{~cm}^{-1}$ for $3 ; \mathrm{g}_{\perp}=2.040$, $\mathrm{g}_{||}=2,241$ and $A_{||}=178.6 \times 10^{-4} \mathrm{~cm}^{-1}$ for 4 .
2.231 and 2.241) consistent with the more energetic $d \rightarrow d$ transition found in its electronic spectrum.

\section{Electrochemistry}

The redox properties of the four proligands and of the four copper(II) complexes were investigated by cyclic voltammetry in acetonitrile solution.

The electrochemical study of the four proligands focuses on the first one-electron oxidation of the phenolic units in view of studying the modulation of this property by the substituting groups. This may allow prediction of the ease of one-electron oxidation of the corresponding copper(II) complexes because the oxidation potential of the protonated free proligand is close to that of the corresponding copper(II) complex (protonation parallels metallation). ${ }^{7} \mathbf{L 1}, \mathbf{L 2}, \mathbf{L 3}$ and $\mathbf{L} \mathbf{4}$ exhibit an irreversible oxidation wave at $\mathrm{E}_{\mathrm{pa}}=0.79$; 0.96; 0.91 and $1.20 \mathrm{~V} v s . \mathrm{Ag} / \mathrm{AgCl}$ (Table 3). These processes correspond to oxidation of the phenolic moieties leading to unstable radical cations, undoubtedly of the phenoxyl type. The $\mathrm{E}_{\mathrm{pa}}$ values of the ligands are consistent with the electronwithdrawing character of the substituents on the phenolic arms. Compared with L1, the substitution by an electronwithdrawing group such as $\mathrm{NO}_{2}(\mathbf{L 3})$, increases $\mathrm{E}_{\mathrm{pa}}$ by $0.12 \mathrm{~V}$ and compared with $\mathbf{L 2}$, the substitution by two electronwithdrawing group such as $\mathrm{NO}_{2}(\mathbf{L} \mathbf{4})$ increases $\mathrm{E}_{\mathrm{pa}}$ by $0.24 \mathrm{~V}$.

The cyclic voltammograms of $\mathbf{1}, \mathbf{2}, \mathbf{3}$ and $\mathbf{4}$, in $\mathrm{CH}_{3} \mathrm{CN}$ at scan rate of $100 \mathrm{mV} \mathrm{s}^{-1}$ are shown in Figures 4 and 5. In the four complexes, the ligands stabilize the copper(II) with respect to copper(I) state, since the reduction of the complexes occurs at low potentials $\left(\mathrm{E}_{\mathrm{pc}}=-0.244 ;-0.700 ;-0.512\right.$ and $-0.842 \mathrm{~V}$ for $\mathbf{1}, \mathbf{2}, \mathbf{3}$ and $\mathbf{4}$, respectively). The cyclic voltammograms of $\mathbf{1}$ and $\mathbf{3}$ have a quasi-reversible redox couple at $\mathrm{E}_{1 / 2}=-0.221$ and $-0.452 \mathrm{~V} v$ s. $\mathrm{Ag} / \mathrm{AgCl},(-0.626$ and $\left.-0.857 \mathrm{~V} v s . \mathrm{Fc}^{+} / \mathrm{Fc}^{0}\right)$ respectively, which can be ascribed

Table 3. Anodic peak potential ${ }^{\mathrm{a}}, E_{p a}$, versus $\mathrm{Ag} / \mathrm{AgCl}\left(\mathrm{Fc} / \mathrm{Fc}^{+}\right)$for the first oxidation of the proligands $\mathbf{L 1}, \mathbf{L 2}, \mathbf{L 3}$ and $\mathbf{L 4}$

\begin{tabular}{|c|c|c|c|c|}
\hline Proligand & $(\boldsymbol{L 1}), \mathrm{H}_{2}$ bbpeten & $(\boldsymbol{L 2}), \mathrm{H}_{3}$ bpeten & $(\boldsymbol{L} 3), \mathrm{H}_{2}$ nbbpeten & (L4), $H_{3}$ bnbpeten \\
\hline$E_{p a} / \mathrm{V}^{\mathrm{b}}$ & $0.79(0.38)$ & $0.96(0.52)$ & $0.91(0.50)$ & $1.20(0.76)$ \\
\hline
\end{tabular}


to the $\mathrm{Cu}^{2+} \leftrightarrows \mathrm{Cu}^{+}$redox couple. Compared with $\mathbf{1}$, the presence of an electron-withdrawing group such as $\mathrm{NO}_{2}$ in the coordination environment of $\mathbf{3}$ increases $\mathrm{E}_{1 / 2}$ by $0.231 \mathrm{~V}$. The cyclic voltammograms of $\mathbf{2}$ and $\mathbf{4}$ show a irreversible reduction at $\mathrm{E}_{\mathrm{pc}}=-0.700$ and $-0.842 \mathrm{~V}$ vs. $\mathrm{Ag} / \mathrm{AgCl},(-1.110$ and $\left.-1.252 \mathrm{~V} v s . \mathrm{Fc}^{+} / \mathrm{Fc}^{0}\right)$ respectively, which can be ascribed to the $\mathrm{Cu}^{2+} \rightarrow \mathrm{Cu}^{+}$process. The reduction process is irreversible for the two complexes and leads to a deposit of copper(0) on the electrode surface, as judged by the observation of a sharp oxidation peak during the reverse scan $\left[\mathrm{E}_{\mathrm{pa}}=-0.242\right.$ and $-0.278 \mathrm{~V}$ vs. $\mathrm{Ag} / \mathrm{AgCl}(-0.652$ and $\left.-0.688 \mathrm{~V} v s . \mathrm{Fc}^{+} / \mathrm{Fc}^{0}\right)$, respectively] with the typical features of a redissolution process. ${ }^{9}$ However, compared with $\mathbf{2}$, the substitution by two electron-withdrawing $\mathrm{NO}_{2}$ group on the phenolic arms of the ligand in $\mathbf{4}$ also increases $\mathrm{E}_{\mathrm{pc}}$ by 0.142 $\mathrm{V}$. The most easily one-electron oxidizable proligand is $\mathrm{H}_{2}$ bbpeten - L1 that has one phenol moiety with no electrondonating or withdrawing group. The complex

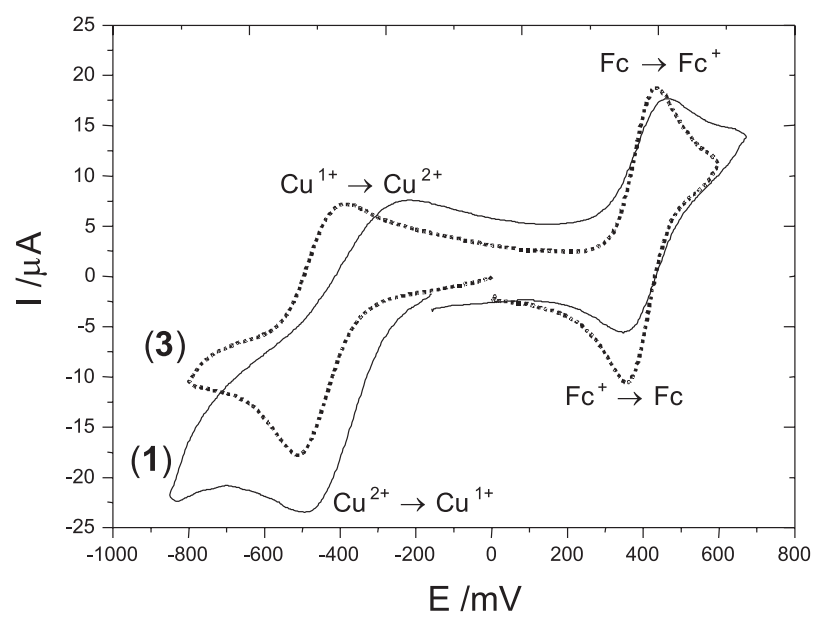

Figure 4. Cyclic voltammograms of $\mathbf{1}$ and $\mathbf{3}$ in $\mathrm{CH}_{3} \mathrm{CN}\left(0.1 \mathrm{~mol} \mathrm{~L}^{-1}\right.$ $\mathrm{TBAPF}_{6}$ ), carbon working electrode, $\mathrm{Ag} / \mathrm{AgCl}$ reference electrode and platinum wire electrode; scan rate $100 \mathrm{mV} \mathrm{s}^{-1}$.

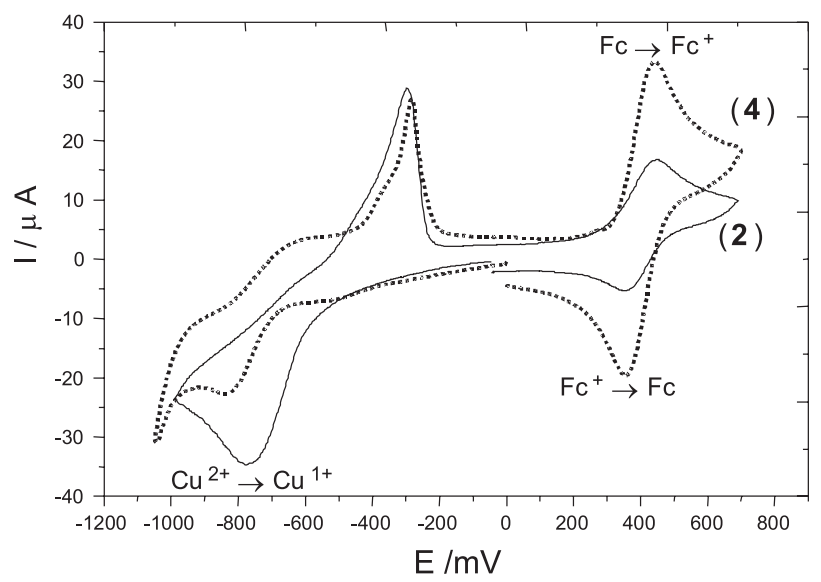

Figure 5. Cyclic voltammograms of 2 and 4 in $\mathrm{CH}_{3} \mathrm{CN}\left(0.1 \mathrm{~mol} \mathrm{~L}^{-1}\right.$ $\mathrm{TBAPF}_{6}$ ), carbon working electrode, $\mathrm{Ag} / \mathrm{AgCl}$ reference electrode and platinum wire electrode; scan rate $100 \mathrm{mV} \mathrm{s}^{-1}$.
$\left[\mathrm{Cu}\left(\mathrm{H}_{2}\right.\right.$ bbpeten $\left.)\right]\left(\mathrm{NO}_{3}\right)_{2} \mathbf{1}$ has a reduction potential more cathodically shifted than 2,3 and $\mathbf{4}$.

\section{Conclusions}

Four $\mathrm{Cu}^{\mathrm{II}}$ complexes containing four polyfunctional ligands, where two of which bear no substituent at the phenol moieties (L1 and L2) and the other two bear an electron-withdrawing $\mathrm{NO}_{2}$ group at one or two of the phenol moieties ( $\mathbf{L 3}$ and $\mathbf{L 4}$ ), have been prepared and characterized electrochemically and spectroscopically. The four compounds have absorption spectra bands in the ranges 665-636 (broad and distorted) and 422-463 nm due to d-d transitions. The EPR spectra showed that the four copper(II) coordination compounds have axial symmetry and a distorted square-pyramidal environment like the galactose oxidase. Electrochemical measurements gave $\mathrm{E}_{\mathrm{pa}}$ values in agreement with the electron-withdrawing character of the substituents on the phenolic arms of the respective ligands. The substitution by $-\mathrm{NO}_{2}$ stabilizes the copper(II) state by several hundred of millivolts. Electronwithdrawing substituent such as $-\mathrm{NO}_{2}$ do not lower the oxidation potential of the phenol groups, just like the thioether linked in the ortho-position of the phenolate oxygen of the Tyr 272 of the enzyme Goase does. Further investigations of electron-donating substituents in the phenolic arms of the ligands are now in progress.

The major influence of the substitution of the phenolic moieties by electron-withdrawing substituent such as $\mathrm{NO}_{2}$ implies to us that it was not necessary to add base during the preparation of the copper complexes $\mathbf{3}$ and $\mathbf{4}$, to obtain coordinated deprotonated phenol groups due the greater acidity of the respective ligands.

The results are consistent with the structures proposed for the copper(II) compounds presented in Figure 6.
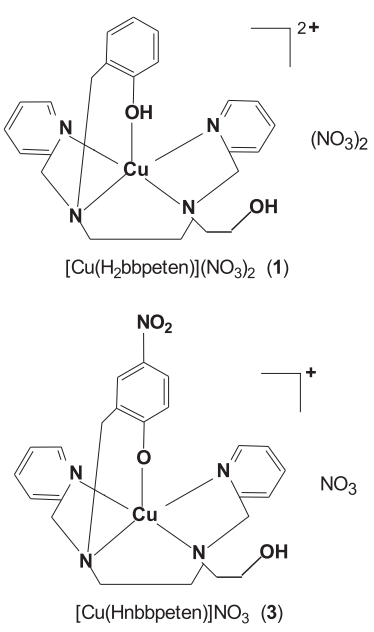
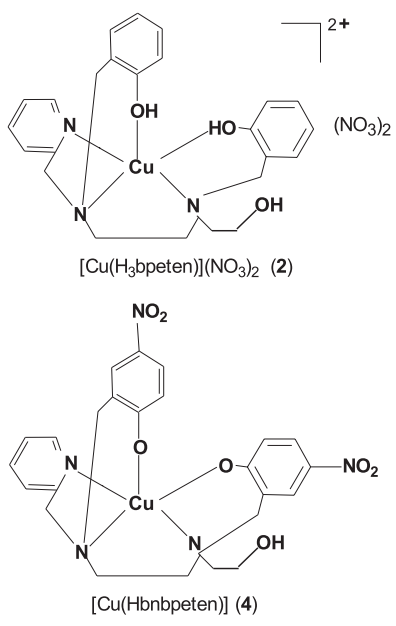

Figure 6. Proposed structures of 1, 2, 3 and 4. 


\section{Acknowledgements}

This work was supported by grants from Fundação Araucária, UFPR/TN and PADCT.

\section{References}

1. Kaim, W.; Schwederski, B.; Bioinorganic Chemistry: Inorganic Elements in the Chemistry of Life, Wiley: New York, 1994.

2. Adams, H.; Fenton, D.E.; Haque, S.R.; Spey, S.E.; Inorg. Chem. Comm. 2000, 3, 83.

3. Amundsen, A.R.; Whelan, J.; Bonich, B.; J. Am. Chem. Soc. 1977, 99, 6730.

4. Whittaker, J.W. In Metal Ions in Biological Systems; Sigel, H. and Sigel, A., eds., Marcel Dekker: New York, 1994, pp. $315-$ 360, vol. 30.

5. Ito, N.; Phillips, S.E.V.; Stevens, C.; Ogel, Z.B.; McPherson, M.J.; Keen, J.N.; Yadav, S.E.V.; Knowles, P.F.; Faraday Discuss. 1992, 93, 75.

6. Itoh, S.; Taki, M.; Fukuzumi, S.; Coord. Chem. Rev. 2000, 198, 3.

7. Ménage, S.; Gellon, G.; Pierre, J-L.; Zurita, D.; Saint-Aman, E.; Bull. Soc. Chim. Fr. 1997, 134, 785.

8. Adams, H.; Bailey, N.A.; Campbell, I.K.; Fenton, D.E.; He, QY.; J. Chem. Soc., Dalton Trans. 1996, 2233.
9. Zurita, D.; Scheer, C.; Pierre, J-L.; Saint-Aman, E.; J. Chem. Soc., Dalton Trans 1996, 4331.

10. Neves, A.; Romanowski, S.M.deM.; Vencato, I.; Mangrich, A.S.; J. Chem. Soc., Dalton Trans, 1998, 4, 617.

11. Neves, A.; Romanowski, S.M.deM.; Bortoluzzi, A.J.; Mangrich, A.S.; Inorg. Chim. Acta, 2001, 313, 137.

12. Romanowski, S.M. de M.; Mangrich, A.S.; Neves, A.; Quim. Nova, 2001, 24, 592.

13. Gagné, R.R.; Koval, C.A.; Lisensky, G.C.; Inorg. Chem. 1980, 19, 2854.

14. Geary, W. J.; Coord. Chem. Rev. 1971, 7, 81.

15. Jameson, R.F. In Metal Ions in Biological Systems; Sigel, H., ed., Dekker: New York, 1981, pp. 1-30, vol. 12.

16. Ettinger, M.J.; Biochemistry 1974, 13, 1242.

17. Rajendran, U.; Viswanathan, R.; Palaniandavar, M.; Lakshminarayanan, M.; J. Chem. Soc., Dalton Trans. 1994, 1219.

18. Giordano, R.S.; Bereman, R.D.; Kosman, D.J.; Ettinger, M.J.; J. Am. Chem. Soc. 1974, 96, 1923.

19. Sakagushi, U.; Addison, A.W.; J. Chem. Soc., Dalton Trans. 1979, 600 .
Received: July 4, 2003

Published on the web: November 5, 2004 